\title{
Analysis of the systems of ventilation of residential houses of Ukraine and Estonia
}

\author{
Olena Savchenko, Vasyl Zhelykh, Hendrik Voll \\ Lviv Polytechnic National University \\ Heat, Gas Supply and Ventilation, Institute of Building and Environmental Engineering \\ e-mail: o.savchenko@i.ua, v_zhelykh@msn.com \\ Tallinn University of Technology \\ Department of Civil Engineering and Architecture \\ e-mail: hendrik.voll@ttu.ee
}

\begin{abstract}
The most common ventilation system in residential buildings in Ukraine is natural ventilation. In recent years, due to increased tightness of structures, an increase in the content of synthetic finishing materials in them, the quality of microclimate parameters deteriorated. One of the measures to improve the parameters of indoor air in residential buildings is the use of mechanical inflow and exhaust ventilation system. In this article the regulatory documents concerning the design of ventilation systems in Ukraine and Estonia and the requirements for air exchange in residential buildings are considered. It is established that the existing normative documents in Ukraine are analogous to European norms, which allow design the system of ventilation of residential buildings according to European standards. However, the basis for the design of ventilation systems in Ukraine is the national standards, in which mechanical ventilation, unfortunately, is provided only for the design of high-rise buildings. To maintain acceptable microclimate parameters in residential buildings, it is advisable for designers to apply the requirements for designing ventilation systems in accordance with European standards.
\end{abstract}

Key words: microclimate parameters, natural ventilation system, mechanical ventilation system, air exchange

\section{Introduction}

The quality of indoor air in residential buildings depends on many factors: the number of inhabitants, the length of their stay in the premise, cooking, washing and ironing of linen, the presence of synthetic finishing materials, etc. In recent years, due to increased tightness of structures, the quality of microclimate parameters has deteriorated. The presence of a person in airtight enclosed spaces increases the concentration of organic acids, ketones, carbon monoxide, carbon dioxide and hydrocarbons to their level of maximum permissible concentration [1]. And although in the conditions of the operation of residential buildings, their number cannot lead to toxic poisoning rights, but it affects the state of health, work capacity and health of people. Thus, the increase in the number of allergic and asthmatic diseases is associated with a decrease in the quality of indoor air in residential buildings, a 
decrease of the productivity of workers - with the quality of indoor air in the office spaces [2]. In order to maintain the permissible parameters of the microclimate in the premises, in particular temperature, humidity and velocity of indoor air, concentration of harmful substances, a ventilation system is designed. The air is delivered or (and) removed from the room for assimilation of the specified harmful substances. The amount of air (air exchange) can be determined by the number of harmful substances, norms or ach of air exchange depending on the type of premises. The main indicator of air quality in residential buildings is the concentration of carbon dioxide, many works are devoted its definition [3, 4].

\section{The purpose of the work}

Compare approaches to the design of ventilation systems in residential houses and the requirements for the air exchange of their premises in Ukraine and Estonia.

\section{Main material}

In Ukraine, as in the countries of the European Union, the normative document DSTU B EN 13779: 2011 [5], which describes the classification of the quality of internal air was introduced. Thus, four classes of internal air quality, the characteristics of which are given in Table 1, are proposed.

Table 1: Basic classification of indoor air quality (IDA) [5]

\begin{tabular}{|c|c|}
\hline Category & Description \\
\hline IDA 1 & High indoor air quality \\
IDA 2 & Medium indoor air quality \\
IDA 3 & Moderate indoor air quality \\
IDA 4 & Low indoor air quality \\
\hline
\end{tabular}

In [5] it is specified that the special values of the quality parameters for indoor air in the room are chosen in accordance with national norms. The recommended typical values of the quality parameters for indoor air in the premises are given in DSTU B EN 15251: 2011 [6], in particular, the distribution of premises according to the categories of the internal environment (Table 2) and the requirements for air exchange in different premises (Table 3) are presented.

Table 2: Description of the applicability of the categories used [6]

\begin{tabular}{|c|l|}
\hline Category & \multicolumn{1}{|c|}{ Explanation } \\
\hline I & $\begin{array}{l}\text { High level of expectation and is recommended for spaces occupied by very } \\
\text { sensitive and fragile persons with special requirements like handicapped, } \\
\text { sick, very young children and elderly persons. }\end{array}$ \\
II & $\begin{array}{l}\text { Normal level of expectation and should be used for new buildings and } \\
\text { renovations } \\
\text { An acceptable, moderate level of expectation and may be used for existing } \\
\text { buildings } \\
\text { Values outside the criteria for the above categories. This category should } \\
\text { only be accepted for a limited part of the year }\end{array}$ \\
III
\end{tabular}


For premises of residential buildings, the requirements for the quantity of external air and removal of contaminated air are given in Table 3 [6].

Table 3: Requirements for air exchange of premises of residential buildings in accordance with the category of indoor microclimate of the premises [6]

\begin{tabular}{|c|c|c|c|c|c|c|c|}
\hline \multirow{3}{*}{ Category } & \multirow{3}{*}{$\begin{array}{c}\text { Air } \\
\text { change } \\
\text { rate, } \\
1 /\left(\mathrm{s} \cdot \mathrm{m}^{2}\right)\end{array}$} & \multirow{3}{*}{$\begin{array}{c}\text { Ach } \\
\text { air } \\
\text { change }\end{array}$} & \multicolumn{2}{|c|}{ Outdoor air flow } & \multicolumn{3}{|c|}{ Exhaust air flow } \\
\hline & & & $\begin{array}{l}\text { Living } \\
\text { room }\end{array}$ & Bedrooms & Kitchen & Bathrooms & Toilets \\
\hline & & & $1 /(s \cdot$ pers $)$ & $1 /\left(s \cdot m^{2}\right)$ & $1 /\left(s \cdot m^{2}\right)$ & $1 /\left(s \cdot m^{2}\right)$ & $1 /\left(s \cdot m^{2}\right)$ \\
\hline $\mathrm{I}$ & 0,49 & 0,7 & 10 & 1,4 & 28 & 2 & 14 \\
\hline II & 0,42 & 0,6 & 7 & 1,0 & 20 & 15 & 10 \\
\hline III & 0,35 & 0,5 & 4 & 0,6 & 14 & 10 & 7 \\
\hline
\end{tabular}

Since currently in Ukraine there are national norms of DBN V.2.2-15-2005 [7] and DBN V.2.5-67: 2013 [8], the specific values of the air quality parameters when designing the ventilation systems of dwelling houses are taken in accordance with their requirements.

Thus, according to DBN V.2.2.15-2005, in Ukraine, exhaust ventilation system with natural stimulation is used in existing residential buildings (Fig. 1).

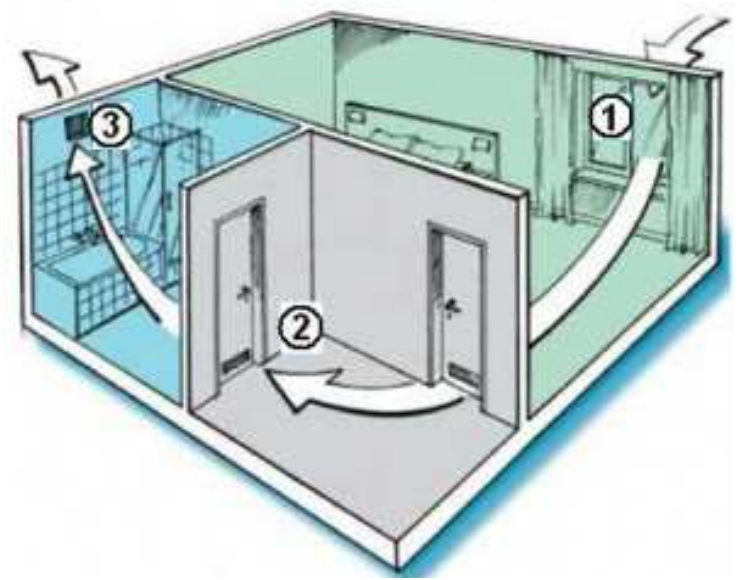

Figure 1: Natural inflow and exhaust ventilation of residential buildings [9].

Air removal is carried out by individual channels from each apartment from the kitchen, bathroom and bathroom, which overlook the roof of the house or with prefabricated vertical channels, which are combined in the attic with horizontal boxes with a common exhaust shaft on the roof. The amount of exhaust air from the premises is determined by the air balance of the apartment, but not less than the indicated values (Table 4).

Table 4: Requirements for air exhaust system ventilation of residential buildings [7]

\begin{tabular}{|l|c|}
\hline \multicolumn{1}{|c|}{ Premise } & Minimum amount of exhaust air, $\mathrm{m}^{3} / \mathrm{h}$ \\
\hline Kitchen-dining room, kitchen & 90 \\
Bathrooms & 25 \\
Toilets & 50 \\
Shared bathroom & 50 \\
\hline
\end{tabular}


The supply of fresh air according to [7] in the volume of single air exchange must be carried out through windows, and when installing windows with a tight shelter, it is necessary to apply modifications of windows with built-in ventilation valves.

In Ukraine, for the inflow of fresh air in the presence of sealed windows in the house uses window ventilation valves. The window ventilation valve is mounted on the top of the window frame and is intended for the supply of external air in residential and non-residential premises. It consists of an external panel 1, which is mounted outside of the room, and a regulator 2, which is mounted on the inside of the window (Fig. 2). These elements are joined by a slit 3, through which the outside air enters the premise. To control the amount of supply air in the outer panel of the vent valve, there is an automatic valve 4. For protection against insects in the design of the ventilation valve there is a protective mesh 5 . The internal regulator directs the air jet upward. The sloping lath 6 allows you to manually adjust the flow of external air. You can also adjust the amount of outside air using special laces 7.

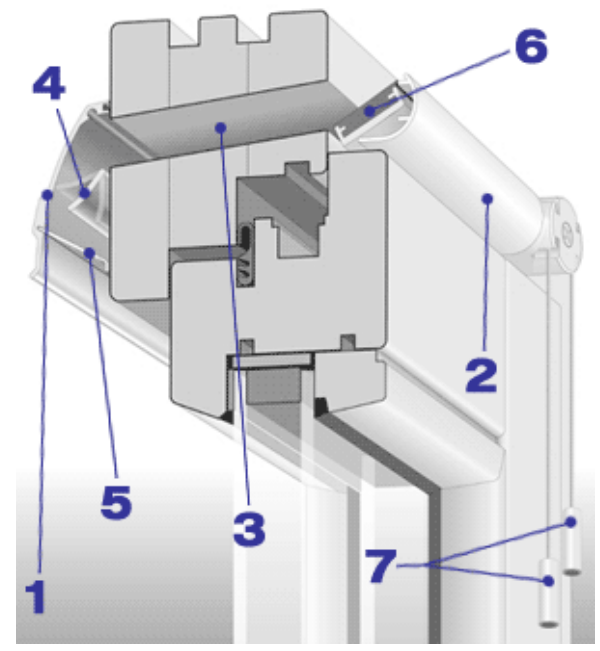

Figure 2: Window ventilation valve design [10]

1 - external panel, 2 - regulator, 3 - slit, 4 - automatic valve, 5 - protective mesh, 6 - sloping lath, 7 - laces.

For design of ventilation systems of high-rise buildings are particular norms DBN V.2.2-24: 2009 [11], in which it is stated that mechanical or mixed ventilation systems can be use for the provision of standard values of air exchange. Moreover, the inflow of air is carried out to the kitchen and residential premises through ventilation valves, which are installed in the designs of windows or in external walls with the possibility of adjustment or with the help of ventilators. Air removal should be carried out from kitchens, toilets and bathrooms through exhaust air ducts or ducts with regulated valves or grates. In addition, it is possible to have an individual mechanical ventilation system.

For the supply of outside air in the room, ventilation valves can be used which are mounted in the exterior wall. They represent the circular pipes 1 , which are mounted on the outer wall and are covered with grates on both sides (Fig.3). The supply of external air is carried out with the help of a ventilator 3. In addition, the tidal air can preheat and filter in the ventilation valve housing. Such ventilation valves can be equipped with carbon filters 4 that prevent the entry of harmful substances from the outside air. The amount of air supplied by the air ventilation valve can be adjusted with the valve located on the inner grate. 


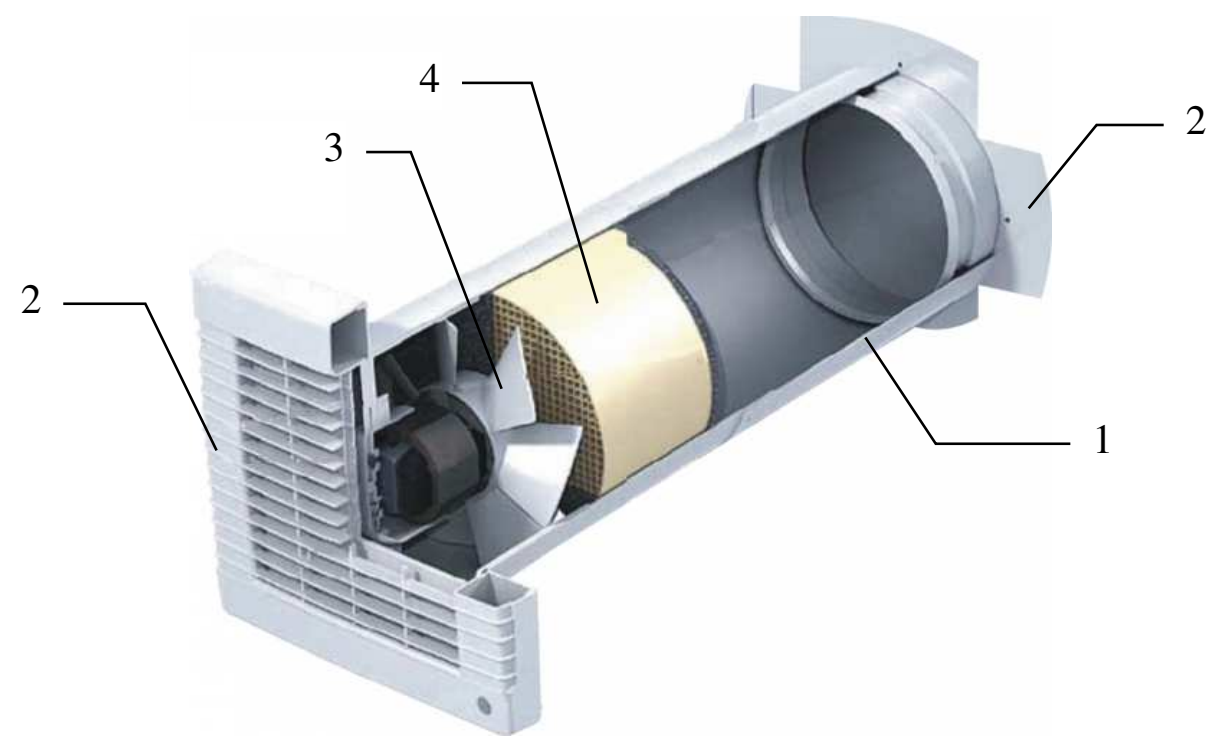

Figure 3: The ventilation valve in the exterior wall [12]

1 - circular pipes, 2 - grate, 3 - ventilator, 4 - filter

In 2013, DBN V.2.5-67: 2013 [8] was implemented, in which there are no clear requirements for the selection and design of ventilation systems in residential buildings. It is indicated that mechanical ventilation should be foreseen if the meteorological conditions and air purity cannot be provided with natural ventilation. The inflow of external air into the room must be carried out through special tidal devices in external walls or in windows.

In the Ukraine in-wall inflow and exhaust ventilation units with heat recuperators [13] and ventilation valves on a solar panel [14] are presented, but they have not become widely used.

In Estonia, up to 90 years of the last century also used natural ventilation. The air was removed through the exhaust ducts in the kitchens, bathrooms and toilets, and fresh air was fed through windows. As is known, when calculating the exhaust natural ventilation system, the temperature of the outside air is assumed to be equal to $+5^{\circ} \mathrm{C}$. At external air temperatures $\geq+5^{\circ} \mathrm{C}$, air exchange is reduced, which leads to deterioration of sanitary and hygienic parameters in residential buildings. In addition, during operation, ventilation exhaust ducts can be damaged, which contributes to the flow of internal air to adjacent apartments.

Since 1991, in Estonia, when designing a ventilation system in residential buildings, Finnish norms NBC-D2 are used, which foresees the design of mechanical inflow and exhaust ventilation. Moreover, the inflow of air is carried out in the room of the bedroom and living room, respectively, $0.5 \mathrm{l} /\left(\mathrm{s} \cdot \mathrm{m}^{2}\right)$ and $0.7 \mathrm{l} /\left(\mathrm{s} \cdot \mathrm{m}^{2}\right)$, and the removal of air is carried out from the premises of the kitchen, bath and toilet, respectively, in amounts of $72 \mathrm{~m}^{3} / \mathrm{h}, 54 \mathrm{~m}^{3} / \mathrm{h}$ and $54 \mathrm{~m}^{3} / \mathrm{h}$. Since 2000, the Estonian norms EVS 845-2: 2004 have been put into effect, in which the requirements for air exchange of residential buildings were the same as in Finnish norms. In 2007, the European standards EVS-EN 15251: 2007 [15] were put into operation, which are known in Ukraine as DSTU B EN 15251: 2011, which, as stated above, set the requirements for the supply of clean air to bedrooms and living rooms and Removal of contaminated air from the kitchen, bath and toilet for different categories of microclimate premises. In addition, it was indicated that in the reconstruction of ventilation systems the microclimate of buildings should meet the category II (Table 2).

As a ventilation unit in apartments in Estonia, in-wall inflow-exhaust ventilation units with heat recuperator can be installed (Fig. 4). 


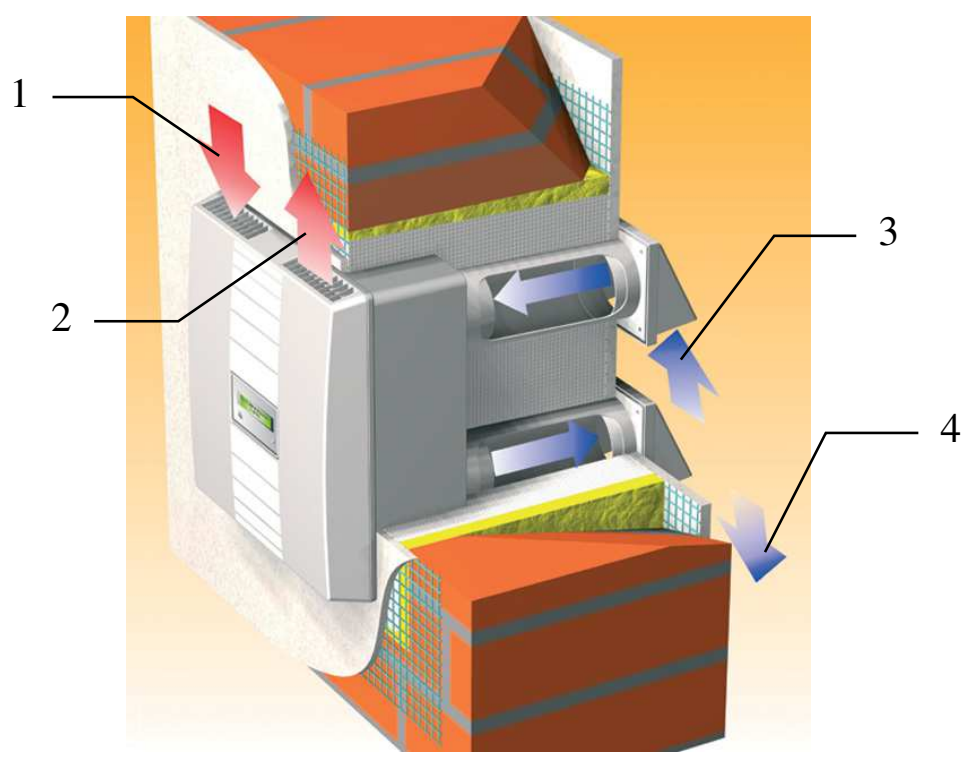

Figure 4: The principle of work of the in-wall inflow-exhaust unit with heat recuperator [16]

1 - indoor air, 2 - inflow air, 3 - external air, 4 - exhaust air

The inflow-exhaust ventilation installation is mounted on the outer wall at the top of the premise. Two openings for pipelines are made in the wall to feed the outside air and remove the exhaust air in the wall. The installation consists of two fans, two filters and a heat recuperator. The principle of work of the in-wall inflow-exhaust unit is as follows. The ventilator supplies the indoor air to the filter, where it is cleaned, and enters the heat exchanger. The second ventilator takes away the external air, which, after cleaning in the filter, is also fed to the heat exchanger. In the heat exchanger, the internal air gives its heat to the outside air through the plates that separate these two air streams.

Different variants of ventilation units with heat exchangers are investigated at Tallinn Technological University (TTU) and their efficiency in maintaining the parameters of microclimate of internal air both in laboratory (Fig. 5) and in real conditions [17].

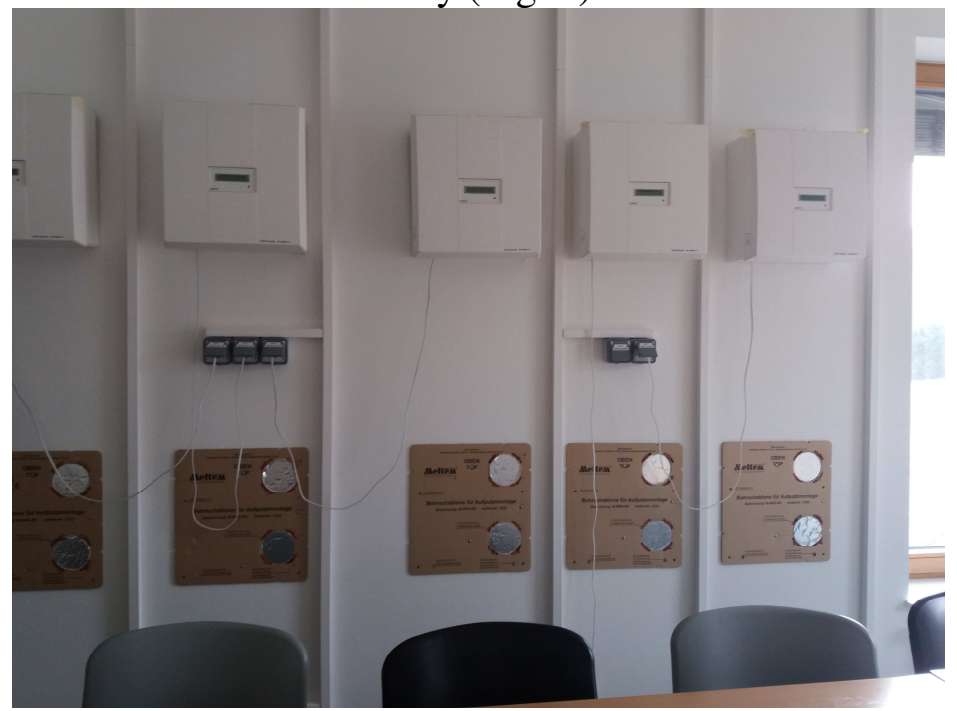

Figure 5: Laboratory stands for the study of in-wall ventilation units with heat recuperators in TTU 
As shown by the study [17], in-wall ventilation inflow-exhaust units with heat recuperators can provide the necessary parameters of indoor air indoors and save heat energy when reconstructing ventilation systems in residential buildings.

Together with the introduction of new standards for the quality of indoor air of premises in residential buildings, large-scale studies of the microclimate of existing buildings [17, 18, 19] are carried out in Estonia, the purpose of which is to establish of the need of using mechanical inflow and exhaust ventilation in such buildings. It has been established that individual energy efficiency measures do not significantly affect the use of energy. Therefore, a complex of energy saving measures is proposed: insulation of external walls, replacement of windows, installation of ventilation systems with heat recovery and use of solar collectors for hot water preparation [20]. The following variants are recommended for renovation of ventilation systems of existing buildings [19]:

- mechanical inflow-exhaust ventilation with ventilation unit in the apartment;

- central exhaust system of mechanical ventilation and supply of inflow air through radiators and valves of fresh air;

- mechanical exhaust ventilation from the kitchen and sanitary premises, installation of radiators and valves of fresh air.

\section{Conclusion}

Despite the existence of identical regulatory documents in Ukraine and Estonia regarding the design of residential ventilation systems and the requirements for air exchange in their premises, in Ukraine, when designing ventilation systems for dwelling houses, in addition to high-rise buildings, there was no widespread use of the mechanical ventilation systems. This leads to unsatisfactory microclimate parameters in residential buildings, in particular, significant concentrations of carbon dioxide, increased relative humidity of air and the appearance of fungi and mold on the internal surfaces of external walls. The results of real studies of the internal microclimate of existing buildings in Estonia confirm the necessity of using mechanical inflow-exhaust ventilation in residential buildings, in particular in Ukraine. One of the ways to accomplish this task is to bring national Ukrainian norms to European standards.

\section{References}

[1] E. O. Shilkrot, Yu. D. Gubernskiy. Skolko vozduha nuzhno cheloveku dlya komforta? AVOK, 2008, №4. https://www.abok.ru/for_spec/articles.php?nid=3996

[2] P. Ole Fanger. Kachestvo vnutrennego vozduha v zdaniyah, postroennyih v holodnom klimate i ego vliyanie na zdorove, obuchenie i proizvoditelnost truda lyudey. AVOK, 2006, №2. https://www.abok.ru/for_spec/articles.php?nid=3185

[3] Kapalo P., Domnita F., Bacotiu C., Voznyak O.T. Determination of the volume air exchange in the apartment. Visnyk Natsional'noho universytetu "L'vivs'ka politekhnika" "Teoriya i praktyka budivnytstva”, 2016, № 844, p.266-271. 
[4] A.lo Mikola, Teet-Andrus Koiv. Indoor air Quality in apartment buildings of Estonia. Computers and Simulation in Modern Science: Selected Papers from WSEAS Conferences, 2011, V, p. 257261.

[5] DSTU B EN 13779:2011. Ventylyatsiya hromads'kykh budivel'. Vymohy do vykonannya system ventylyatsiyi ta kondytsiyuvannya povitrya, 2012, 116 p.

[6] DSTU B EN 15251:2011. Rozrakhunkovi parametry mikroklimatu prymishchen' dlya proektuvannya ta otsinky enerhetychnykh kharakterystyky budivel' po vidnoshennyu do yakosti povitrya, teplovoho komfortu, osvitlennya ta akustyky. 2012, 71 p.

[7] DBN V.2.2-15-2005. Budynky i sporudy. Zhytlovi budynky. Osnovni polozhennya. 2005, 45 p.

[8] DBN V.2.2-67:2013. Opalennya, ventylyatsiya ta kondytsiyuvannya. 2013, 141 p.

[9] Kak pravilno sdelat sistemu ventilyatsii $v$ chastnom dome. http://personalhouse.net/kommunikacii/ventilyaciya/sistema-ventilyacii-chastnogo-doma

[10] Okonnyie provetrivateli. Voprosyi $i$ otvetyi pro okonnyie provetrivateli http://js.com.ua/articles/okno_provetrivateli/

[11] DBN V.2.2-24:2009. Budynky i sporudy. Proektvannya vysotnykh zhytlovykh i hromads'kykh budynkiv. 2009, 103 p.

[12] Yak zrobyty zahal'noobminnu ventylyatsiyu dlya zhytlovykh prymishchen'? https://alterair.ua/uk/articles/obscheobmennaya-ventilyatsiya-dlya-zhilya

[13] Provetrivateli v Ukraine. http://zakupka.com/t/provetrivateli-716/

[14] Pryrodna ventylyatsiya na sonyachniy enerhiyi dlya kotedzhnoho mistechka "Vyshneve" m. Kyyiv. https://klimapro.com.ua/pryrodnoyi-s-kotedzhne-mistechko-Vyshneve-Kyyiv

[15] EVS-EN 15251: 2007. Indoor environmental input parameters for design and assessment of energy performance of buildings addressing indoor air quality, thermal environment, lighting and acoustics.

[16] Ventilyatsionnaya ustanovka MELTEM. http://arkodan.com/kondicionirovaniya-iventiljacija/vent-meltem/

[17] Alo Mikola, Teet-Andrus Koiv, Hendrik Voll. (2014) Ventilation of Apartment Buildings and Nursing Homes. http://file.scirp.org/pdf/SGRE_2014051211365152.pdf

[18] Kalamees T. (2006). Indoor Climate Conditions and Ventilation Performance in Estonian Lightweight Detached Houses. Indoor and Built Environment, (15, 6), 555 - 569, ISSN 14230070

[19] Stroitelno-tehnicheskoe sostoyanie zhilyih kirpichnyih domov Estonii i prognoziruemyiy srok ih ispolzovaniya. Otchet ob issledovanii / pod red. T. Kalamees. - Tallinn. - 2010. - $240 \mathrm{~s}$.

[20] Kalle Kuusk, Targo Kalamees (2015): Retrofit cost-effectiveness: Estonian apartment buildings, Building Research \& Information. http://dx.doi.org/10.1080/09613218.2016.1103117 